\title{
ROLE STRESS SEBAGAI MOTIVATOR BAGI AUDITOR: ANALISIS TEORITIS ATAS DASAR TEORI-TEORI MOTIVASI
}

\author{
Francisca Reni Retno Anggraini \\ Fakultas Ekonomi Universitas Sanata Dharma, \\ Mrican CT Depok, Sleman, Yogyakarta 55281, reni@staff.usd.ac.id
}

\begin{abstract}
The purpose of this paper explains the positive side of role stress which has long been regarded as the factor causing performance decrease and ultimately initiates job dissatisfaction. There are many cause factors (antecedent) of role stress such as boundary-spanning activities, ethical climate in organization, mentoring, and organization-professional conflict, which has been proven empirically affecting role stress. Role stress arising in the job relation between manager-subordinate or leader-his or her member is a dynamic process in organization. Role stress becomes potential resource for organization if manager or leader is able to manage it well, so he or she can change it from hygiene factor to motivator. This article tries to correlate role stress phenomenon in public accountant firms with motivation theories to give alternatives in resolving problems in the role stress. Role stress can become a motivator for partners or senior auditors to be able to suit job characteristics and reward/punishment award mechanism with personal characteristics of auditors, reduce boundary spanning activities and environment uncertainty perception, increase understanding among all individuals in the public accountant firm regarding demand, values, and norms of the said public accountant firm, and ultimately establish specific and attainable goals. This article aims to be a contribution for management (partners and senior auditors) in motivating auditors to increase their performance and for researchers to inspire empiric research related to role stress as a motivator to increase performance.
\end{abstract}

Keywords: role stress, motivation theory, performance

\begin{abstract}
ABSTRAK
Artikel ini bertujuan untuk mengungkapkan sisi positif dari role stress yang selama ini dianggap sebagai faktor penyebab terjadinya penurunan kinerja dan pada akhirnya menimbulkan job dissatisfaction. Ada beberapa faktor penyebab (antecedent) dari role stress yaitu boundary-spanning activities, iklim etis perusahaan, mentoring, dan organization-proffesional conflict yang telah terbukti secara empiris berpengaruh terhadap role stress. Role stress yang muncul di dalam hubungan kerja atasan-bawahan atau ketua-anggota kelompok merupakan proses dinamis yang terjadi di dalam organisasi. Role stress dapat menjadi sumber potensial bagi organisasi apabila manajer atau ketua dapat mengelolanya dengan baik, sehingga dapat mengubah role stress dari hygiene factors menjadi motivator. Artikel ini mencoba mengaitkan fenomena role stress di dalam kantor akuntan publik (KAP) dengan teori-teori motivasi dengan tujuan untuk memberikan alternatif untuk mengatasi permasalahan yang berkaitan dengan role stress. Role stress dapat diubah menjadi motivator partner atau auditor senior dapat menyesuaikan karakteristik tugas dan mekanisme pemberian reward dan punishment dengan karakteristik personal dari auditor, mengurangi boundary-spanning activities dan ketidakpastian lingkungan persepsian, meningkatkan pemahaman bagi seluruh individu di dalam KAP terhadap kebutuhan, nilai-nilai, dan norma-norma yang dimiliki KAP tersebut, dan membuat specific goals dan goals yang mudah dicapai. Artikel ini diharapkan dapat memberi kontribusi bagi manajemen (partner dan auditor senior) di dalam KAP dalam memotivasi auditor untuk meningkatkan kinerjanya. Selain itu juga diharapkan dapat memberi inspirasi untuk melakukan studi empiris dalam kaitannya dengan role stess yang dapat digunakan sebagai motivator dalam meningkatkan kinerjanya.
\end{abstract}

Kata Kunci: role stress, teori motivasi, kinerja 


\section{PENDAHULUAN}

Pengelolaan sumber daya manusia di dalam suatu perusahaan merupakan hal yang sangat penting karena sumber daya manusia merupakan aset bagi perusahaan, yang berperan penting dalam pencapaian kesuksesan perusahaan. Kesuksesan ini akan tergantung pada bagaimana perusahaan dapat memotivasi, memberi pelatihan, dan membuat mereka puas dengan pekerjaannya (Belkauoi, 1989). Pengelolaan sumber daya manusia menjadi hal yang sangat krusial di dalam perusahaan jasa karena pendapatan mereka bersumber dari kemampuan karyawan melaksanakan jasa.

Kahn et al. (1964), pencetus teori dinamika peran (role dynamics theory), mengatakan bahwa teori dinamika peran didasarkan pada episode-episode peran, yaitu proses siklis antara role sender dan focal person (pelaksana peran) (dikutip oleh Viator, 2001). Teori tersebut menyatakan bahwa role sender memiliki ekspektasi atas dasar perilaku focal person dan berusaha mempengaruhi perilaku focal person dengan memberikan informasi mengenai ekspektasi peran. Focal person merespon dengan menerima atau menolak informasi tersebut atas dasar persepsi mereka terhadap role-sendings. Ketika terdapat divergensi preferensi antara role sender (prinsipal) dan focal person (agen) serta adanya informasi yang tidak lengkap, maka akan terjadi role stress (Maher, Ramanathan, and Peterson, 1979). Hal ini akan mengakibatkan agen tidak dapat melaksanakan pekerjaannya sesuai dengan kepentingan terbaik dari prinsipal.

Role stress terdiri dari 2 konstruk penting, yaitu role ambiguity dan role conflict (Kahn, 1964) (dikutip oleh Fisher, 2001). Role ambiguity terjadi dalam lingkungan pekerjaan di mana seorang karyawan kurang memperoleh informasi yang memadai bagi kinerja yang efektif dari peran yang diberikan (Sinatra, 1980). Sedangkan role conflict didefinisikan sebagai tingkat ketidaksesuaian dari ekspektasi, yang dikomunikasikan oleh role sender (pemberi peran) pada role incumbent atau focal person atau penerima peran (Rebele dan Michaels, 1990).

Breaugh dan Colihan (1994) mengatakan bahwa role ambiguity tidak selalu dapat didefinisikan dengan baik. Hal ini umumnya dapat diterima karena role ambiguity terjadi ketika individu kurang memiliki definisi yang jelas terhadap ekspektasi peran mereka dan metode yang dikehendaki untuk mengisi tugas-tugas mereka. Kurangnya kejelasan ini berhubungan dengan tugas, otoritas atau pertanggungjawaban dalam pikiran manajer atau dalam pikiran dari individu yang bekerja dengannya (dikutip oleh Veloutsou dan Panigyrakis, 2004).

Rizzo, House, dan Lirtzman (1970) serta Sounder (1981) mengatakan bahwa role conflict adalah inkompatibilitas antara persyaratan dengan ekspektasi dari peran, di mana kompatibilitas ditentukan relatif terhadap seperangkat kondisi dengan suatu impak pada kinerja peran (dikutip oleh Veloutsou et al., 2004). Mennon dan Akhilish (1994) mengatakan bahwa role conflict lebih intensif dalam pekerjaan yang kurang kongkrit sifatnya dan menghendaki pembuatan keputusan dan pemikiran yang lebih abstrak (Veloutsou et al., 2004). Hal ini sering terjadi ketika karyawan tidak ingin melaksanakan tugasnya atau mereka memiliki supervisor dengan ekspektasi yang bertentangan.

Role stress dapat mengakibatkan turunnya motivasi untuk melaksanakan pekerjaannya dengan baik. Hal ini disebabkan focal person tidak dapat melaksanakan pekerjaannya sesuai dengan keinginan role sender. Turunnya motivasi kerja ini pada akhirnya akan mempengaruhi keputusan focal person untuk keluar dari organisasi atau perusahaan tersebut. Di sisi lain, sebenarnya role stress juga merupakan suatu sarana yang dapat digunakan oleh role sender untuk memotivasi focal person menciptakan kreativitas-kreativitas di dalam pekerjaan yang dilakukannya. Pada akhirnya, pekerjaan dapat diselesaikan sesuai dengan keinginan role senders. Oleh karena itu, masalah yang terjadi dalam kaitannya dengan role stress ini adalah bagaimana mengubah peran role stress sebagai sesuatu yang menurunkan motivasi karyawan (Herzberg et al., 1957 menyebutnya sebagai hygiene factors) menjadi 
suatu hal yang sebaliknya, yaitu justru memotivasi karyawan untuk melaksanakan pekerjaan dengan baik. Tujuan ini dapat tercapai ketika perusahaan dapat mendesain pekerjaan bawahan sedemikian rupa sehingga role stress dapat dikurangi atau dihilangkan.

Artikel ini mencoba mengidentifikasi berbagai riset yang telah dilakukan dalam kaitannya dengan role stress, untuk dapat menemukan faktor-faktor yang menjadi penyebab (antecendent) dan menggunakan berbagai teori motivasi untuk mengidentifikasi cara yang dapat digunakan untuk mengubah efek role stress dari sesuatu yang dapat menimbulkan demotivasi menjadi motivasi.

Beberapa penelitian yang berkaitan dengan role stress telah menemukan banyak faktor yang dapat memicu timbulnya role stress (antecedent dari role stress). Faktor-faktor tersebut meliputi adanya boundary-spanning activities (Rebele dan Michaels, 1990), iklim etis (Schwepker dan Hartline, 2005; Thomas, Schermerhorn dan Dienhart, 2004; yang semuanya dikutip oleh Jaramillo et al., 2006), mentoring (Almer dan Kaplan, 2002), Organizational-Professional Conflict, disingkat OPC (Pei dan Davis, 1989), work family conflict (Collins dan Killough, 1992; Elloy, 2001; Gilboa et al., 2005), perceived environment uncertainty (Ferris 1977a; Ferris 1977b), dan budaya (Sinatra, 1980; Chow et al., 2001). Sedangkan faktor-faktor yang menjadi konsekuensi dari role stress, yang diidentifikasi dari berbagai penelitian, meliputi penurunan job satisfaction dan job performance serta peningkatan job-related tension dan turnover intentions.

Ketidakpastian lingkungan persepsian (Perceived Environment Uncertainty, disingkat PEU) merupakan faktor mediasi antara boundary-spanning activities dan role stress. Jadi, kita dapat mengelompokkannya sebagai faktor penyebab (antecedent) dari role stress. Demikian juga dengan budaya, ia juga merupakan faktor mediasi antara iklim etis, mentoring, dan OrganizationalProfessional Conflict dengan role stress. Rebele dan Michaels (1990) menemukan bahwa boundaryspanning activities berhubungan positif, tetapi tidak signifikan dengan role conflict dan berhubungan negatif, tetapi juga tidak signifikan dengan role ambiguity. Akan tetapi, ketika mereka memasukkan variabel mediasi ketidakpastian lingkungan yang dipersepsikan, maka hubungan antara boundaryspanning activities dengan role stress (role conflict dan role ambiguity) menjadi signifikan.

Peran auditor independen umumnya menjadi terganggu oleh 2 komponen dari role stress karena (1) sifat boundary-spanning-nya, (2) potensi terjadinya ketidaksamaan ekspektasi antara klien dan perusahaan, dan (3) kompleksitas dari audit pada masa sekarang dan konsekuensi dari kinerja peran yang buruk (Rebele et al., 1990). Selain itu juga, role stress yang terjadi pada auditor dapat juga disebabkan oleh iklim organisasi (Sinatra, 1980). Singh (1998) menyatakan bahwa interfirm theory dan riset pada boundary-spanning occupations menunjukkan bahwa faktor-faktor organisasional dan berbagai mekanisme yang ada memiliki pengaruh penting pada kejelasan peran atau role clarity (Nygaard dan Dahlstrom, 2002).

Iklim etis di dalam perusahaan juga mempengaruhi role stress. Schwepker dan Hartline (2005) serta Thomas, Schermerhorn dan Dienhart (2004) menemukan persepsi etis mengenai perusahaan berhubungan erat dengan public image dan kesuksesan dalam membina hubungan jangka panjang dengan pelanggan atau klien (Jaramillo, Mulki, dan Solomon, 2006). Karena iklim etis memberi sinyal mengenai perilaku etis, maka iklim etis menjadi antecedent yang penting dari role conflict dan role ambiguity dari salesperson (Jaramillo et al., 2006). Manajer pemasaran yang bekerja dalam organisasi yang lebih etis mengalami role conflict dan role ambiguity yang lebih rendah dibandingkan dengan mereka yang bekerja dalam organisasi yang kurang etis (Chia-Mei dan Chin-Yuan, 2006). Riset di bidang pemasaran menunjukkan bahwa nilai-nilai yang berorientasi pada pasar (perilaku yang lebih mementingkan konsumen dibandingkan dirinya sendiri) mempengaruhi role conflict, role ambiguity, organizational commitment, dan job satisfaction (Farrell, 2005). Etika dapat dipandang sebagai sebagai suatu setting dinamis dari tekanan sosial yang menekan interdependensi seseorang dengan orang lain (Chonko dan Burnett, 1983). Perusahaan yang dapat memberikan pedoman yang jelas dalam kaitannya dengan perilaku etis dari karyawannya akan memberi kejelasan mengenai 
ekspektasi etis sehingga hal ini akan menurunkan stress. Ketika perusahaan atau organisasi memiliki aturan dan prosedur formal dari kinerja, maka hal ini akan dapat mengurangi role conflict (Sinatra, 1980).

Riset yang berkaitan dengan peran mentor dalam menurunkan role conflict dan role ambiguity, terutama dalam auditing, belum memberikan hasil yang konsisten. Ada riset menemukan bahwa ada hubungan positif antara mentoring dengan role conflict (Almer and Kaplan, 2002). Sedangkan riset lain menemukan hubungan positif dan negatif. Ketidakkonsistenan ini mungkin disebabkan oleh tidak dibedakannya bentuk interaksi auditor dengan mentornya (Viator, 2001). Ada 2 bentuk interaksi, yaitu informal dan formal mentor. Formal mentor adalah mentor yang diperlakukan sebagai karyawan perusahaan dengan program organisasional formal. Hal ini berkebalikan dengan informal mentor. Informal mentor adalah mentor yang oleh focal person dianggap memiliki power, kepercayaan diri dan bersedia untuk berbagi dan melindungi. Oleh karena itu, formal akan menjadi kurang mungkin untuk memberikan informasi yang membantu memperjelas peran focal person (mengurangi role ambiguity), mengelola inter-sender dan person-role conflict (mengurangi role conflict), dibandingkan dengan informal mentor. Informal mentor secara signifikan menurunkan tingkat role ambiguity, tetapi tidak untuk role conflict. Sedangkan untuk formal mentor menunjukkan tidak ada hubungan yang signifikan dengan role conflict dan role ambiguity (Viator, 2001).

OPC terjadi ketika nilai-nilai organisasional tidak kompatibel dengan nilai-nilai professional. Sorensen (1967) menyatakan bahwa perhatian organisasi terhadap otoritas dan pengendalian, aturan dan regulasi, dan loyalitas organisasional dapat bertentangan dengan perhatian pemberi kerja professional terhadap otonomi professional dan penjagaan terhadap standar yang tinggi (Bamber dan Iyer, 2002).

Porter et al. (1974) mengatakan bahwa komitmen menunjukkan bahwa (1) kepercayaan pada dan penerimaan terhadap sasaran dan nilai-nilai dari profesi; (2) kemauan untuk menjalankan tugas sesuai dengan perilaku yang diinginkan profesi; dan (3) keinginan yang terbatas untuk menjaga keanggotaan profesi (Aranya, Pollock, dan Amernic, 1981). Aranya et al. (1981) menemukan bahwa organizational commitment memiliki hubungan positif paling kuat dengan professional commitment di samping kepuasan dengan reward. Sedangkan Organizational-Professional Conflict (OPC) berhubungan negatif dengan professional commitment.

OPC dari akuntan yang bekerja dalam organisasi professional lebih rendah dibandingkan akuntan yang bekerja dalam organisasi non professional sehingga di dalam organisasi professional, tingkat konflik persepsian berhubungan negatif dengan posisi dalam hirarki dan job satisfaction dan berhubungan positif dengan turnover intentions (Aranya dan Ferris, 1984; Bamber et al., 2002). OPC dari auditor internal dan role stress dipengaruhi oleh struktur organisasional (Pei dan Davis, 1989).

Beberapa riset mengenai role stress menunjukkan bahwa ketidakpastian lingkungan persepsian dapat memoderasi hubungan antara boundary-spanning activities dengan role stress. Duncan (1972) menyatakan bahwa ketidakpastian lingkungan persepsian berhubungan dengan suatu keadaan ketika individu berperilaku atas dasar pengetahuan yang kurang lengkap dari hubungannya dengan lingkungan. Downey and Slocum (1975) mengatakan bahwa ketika perilaku individu ditentukan dengan lingkungan persepsian tertentu (yaitu respon keperilakuan terhadap stimuli lingkungan persepsian). Hal ini secara logis mengekspektasikan bahwa persepsi terhadap ketidakpastian lingkungan akan memiliki pengaruh pada perilaku individual dan selanjutnya berpengaruh pada kinerja tugas (Ferris, 1977a). Dampak ketidakpastian lingkungan pada job satisfaction telah diuji dalam lingkungan akuntansi. Hasilnya menunjukkan bahwa ketidakpastian lingkungan persepsian berpengaruh terhadap job satisfaction (Ferris, 1977a).

Jaramillo, Mulki, dan Marshall (2005) menyatakan bahwa komitmen organisasional (organizational commitment) berhubungan dengan kecintaan individu pada organisasinya dan 
tercermin dalam kekuatan identifikasi dan keterlibatan individu dalam organisasi (Jaramillo et al., 2006). Aranya et al. (1981) menyatakan bahwa organizational commitment dari individu diukur dengan kekuatan relatif dari identifikasi mereka dengan keterlibatan mereka pada organisasinya. Shepard (1956), Ben-David (1958), dan Gouldner (1958) menyatakan bahwa analisis tradisional terhadap organizational commitment dan professional commitment mengasumsikan bahwa individual telah memilih satu komitmen di antara komitmen yang lain karena ada konflik antara birokratisme dan profesionalisme (Aranya et al., 1981).

Hofstede (1980) mengidentifikasi ada 4 dimensi budaya nasional yang berhubungan dengan pekerjaan, yaitu confucian dynamism, individualism vs. collectivism, masculinity vs. femininity, dan power distance (Chow, Lindquist, dan $\mathrm{Wu}, 2001)$. Chow et al. (2001) menemukan bahwa semakin tinggi power distance menunjukkan bahwa semakin siap mereka menerima high-stretch performance standards. Anggota dari budaya dengan power distance yang tinggi lebih siap menerima ketidaksamaan antar pribadi dan institusinya. Bawahan dari budaya dengan power distance yang tinggi lebih siap menerima keputusan dan keinginan dari atasan.

Chow et al. (2001) juga menemukan bahwa negara dengan budaya collectivism yang tinggi lebih siap untuk menerima high-stretch performance standards. Budaya kolektivisme ini ditunjukkan oleh kemauan individu untuk berkumpul atau berinteraksi dengan orang lain sehingga membentuk suatu kelompok yang kuat dan kohesif. Budaya kolektivisme ini juga menyebabkan individu cenderung untuk lebih mengutamakan kepentingan perusahaan dibandingkan kepentingan dirinya sehingga ketika mereka cenderung tidak melakukan eskalasi terhadap komitmen (Harrison, Chow, Wu, dan Harrell, 1999). Berdasarkan riset di atas, mungkin diperlukan untuk memasukkan variabel ini sebagai moderator hubungan antara role stess dengan antecedent-nya. Negara dengan budaya power distance yang tinggi dan budaya kolektivisme yang tinggi cenderung kurang mengalami role stress, dibandingkan negara dengan power distance yang rendah dan bersifat individualis. Role ambiguity dapat dikurangi jika atasan bersedia mendengarkan dan merespon terhadap ide dan saran bawahan, kecepatan atasan merespon masalah dan membuat keputusan secara tepat waktu, dan kecukupan otoritas yang dimiliki oleh atasan untuk membuat keputusan dan menangani masalah dengan tepat (Sinatra, 1980).

Ada banyak definisi motivasi yang muncul dengan berbagai macam perspektif. Berbagai macam definisi ini muncul karena ada sejumlah alasan mengenai kesulitan dalam mendefinisikan motivasi (Pinder, 1984). Pinder (1984) mengutip pendapat Jones (1955), Vroom (1964), Steer dan Porter (1975), dan Locke, Shaw, Saari, dan Latham (1981) yang menyatakan bahwa motivasi kerja adalah seperangkat kekuatan energetik yang berasal dari dalam maupun dari luar sifat individu untuk memunculkan perilaku yang berhubungan dengan pekerjaan, dan untuk menentukan bentuk, arah, intensitas, dan durasinya.

Pinder (1984) mengatakan bahwa motivasi kerja berbeda dengan kinerja. Perbedaan ini lebih dari sekedar perbedaan semantik karena perbedaan ini memiliki implikasi yang kuat bagi pemahaman dan aplikasi dari teori-teori motivasi. Kinerja dapat didefinisikan sebagai pencapaian sasaran yang terkait dengan kerja, tanpa mendasarkan pada maksud dari pencapaiannya. Sedangkan motivasi adalah kekuatan yang dapat memunculkan kinerja tersebut. Akan tetapi, ketika kekuatan tersebut tidak mampu memunculkan kinerja sesuai dengan standar yang ditetapkan, maka yang terjadi adalah frustasi yang dialami oleh individu tersebut. Hal ini akan berakibat pada penurunan kekuatan untuk mencapai kinerja tersebut. Jadi, ketika motivasi rendah, maka akan menghasilkan kinerja yang rendah.

Ada beberapa teori motivasi yang muncul dari berbagai penelitian tentang motivasi. Teoriteori ini berkembang sejalan dengan fenomena yang ada dalam dunia nyata dalam kaitannya dengan perilaku individu terhadap pekerjaannya. Teori-teori yang berkaitan dengan motivasi yang dibahas secara mendalam oleh Pinder (1984). Teori-teori tersebut meliputi the motivator-hygiene theory, theory $X$ and theory $Y$, equity theory, valence-instrumentality-expectancy theory (VIE theory), theory 
of intentional behavior, dan goal setting theory. Oleh karena itu, pembahasan mengenai teori-teori di atas lebih banyak mengutip dari beberapa penjelasan yang diberikan oleh Pinder (1984) dalam bukunya yang berjudul "Work Motivation: Theory, Issues, and Applications".

Teori motivasi pertama kali dimunculkan oleh Herzberg, et al. (1957), yang kemudian dikenal dengan motivation-hygiene theory. Teori ini menyatakan bahwa job satisfaction secara sederhana tidak berkebalikan dengan job dissatisfaction. Mereka mengatakan bahwa keduanya independen dan seseorang dapat mengalami keduanya. Teori ini dikenal dengan teori 2 faktor karena Herzberg (1957) mengidentifikasi ada 2 faktor yang dapat yang saling bertentangan yang dapat mempengaruhi kinerja, yaitu motivators dan hygiene factors.

Motivators adalah faktor-faktor yang dapat mengakibatkan job satisfaction. Job satisfaction dipandang sebagai konsekuensi dari pertumbuhan, pengakuan (verbal), pekerjaan itu sendiri (tantangan), pertanggungjawaban, dan kemajuan (promosi). Jika kelima faktor tersebut ada di dalam suatu pekerjaan, maka kebutuhan dasar individu akan terpuaskan, dan perasaan positif dan peningkatan kinerja akan terjadi (Miner, 1980: 78). Hygene factors adalah faktor-faktor yang dapat mengakibatkan job dissatisfaction. Faktor-faktor ini meliputi praktik administratif dan kebijakan, supervisi (kualitas teknis), hubungan interpersonal (terutama dengan supervisi), kondisi kerja fisik, job security, manfaat, dan gaji. Ketika faktor-faktor ini ada secara memadai, maka mereka dapat mengubah dissatisfaction dan meningkatkan kinerja sampai pada suatu titik tertentu, tetapi faktorfaktor tersebut tidak dapat dipercaya dapat menghasilkan perasaan kerja yang benar-benar positif atau tingkat kinerja yang tinggi. Untuk mencapai ini, maka manajemen harus dapat menggeser mekanisme dan memindahkannya menjadi motivasi.

Theory X dan Theory Y ini dikemukakan oleh Douglas McGregor. Theory $X$ mengasumsikan bahwa (1) rata-rata manusia dewasa by nature adalah malas, ia bekerja sesedikit mungkin; (2) ia kurang ambisius, tidak suka dengan tanggung jawab dan lebih suka diatur oleh orang lain; (3) ia secara inheren suka untuk bekerja sendiri (selfish) dan indiferen dengan sasaran dan kebutuhan organisasi; (4) ia enggan untuk berubah; dan (5) naïf dan mudah dikelabui oleh motivator (Pinder, 1984: 38-39). Sedangkan Theory $Y$ memiliki asumsi yang berkebalikan dengan Theory $X$. Perbedaan asumsi ini mengakibatkan pendesainan pekerjaan yang berbeda. Oleh karena itu, manajemen perlu memahami karakteristik dari bawahannya sehingga pekerjaan atau tugas yang diberikan sesuai dengan karakteristik mereka, dan pada akhirnya job satisfaction dan kinerja yang tinggi akan tercapai.

Carrell and Dittrich (1978), seperti dikutip oleh Pinder (1984: 115) menyatakan bahwa equity theory memiliki 3 asumsi utama, yaitu (1) orang membangun kepercayaan mengenai sesuatu berupa return yang sama dan fair untuk kontribusinya bagi pekerjaan mereka; (2) orang cenderung membandingkan apa yang mereka persepsikan menjadi argumen mereka dengan pemberi kerja; dan (3) ketika orang percaya bahwa perlakuan mereka sendiri tidak adil, relatif terhadap argumen yang mereka persepsikan dibuat oleh orang lain, mereka akan termotivasi untuk melakukan sesuatu mengenai hal tersebut. Seseorang dapat menerima ketika melihat orang lain mendapat outcome yang lebih banyak dibandingkan dirinya jika ia percaya bahwa orang lain memberi kontribusi lebih banyak dibandingkan dirinya. Tetapi, ketika seseorang melihat orang lain mendapatkan lebih banyak uang (outcome) dibandingkan dirinya, sementara tidak nampak bahwa orang yang lain tersebut memberi kontribusi yang lebih banyak, maka akan muncul kecemasan (tension) yang akan memotivasi individu tersebut untuk menyeimbangkan equity ratio (rasio input dan outcome).

VIE theory mengasumsikan bahwa seseorang mendasarkan tindakannya pada persepsi dan kepercayaan (beliefs). Pengujian terhadap teori ini dilakukan dengan menguji 3 komponen mental penting yang dipandang sebagai perilaku yang mengarahkan dan yang memulai, yaitu Valence, Instrumentality, dan Expectancy (Pinder, 1984: 133). Vroom (seperti dikutip oleh Pinder, 1984: 134) mengatakan bahwa istilah valensi (valence) berhubungan dengan orientasi afektif (emosional) yang dimiliki seseorang atas dasar outcome yang akan diperoleh. 
Outcome dikatakan menjadi valensi secara positif bagi seseorang jika ia lebih suka untuk memilikinya. Sebaliknya, outcome di mana seseorang lebih suka untuk menghindarinya merupakan valensi negatif, misalnya kecemasan, stress, dan pemecatan. Akan tetapi, ketika orang berperilaku indeferen terhadap suatu outcome tertentu, maka ia memiliki valensi nol. Sedangkan konsep instrumentalitas berkaitan dengan pencapaian outcome yang lain (second level outcome). Vroom (dikutip oleh Pinder, 1984: 135) mengatakan bahwa sesuatu dikatakan instrumental jika ia membantu mencapai atau mempertahankan sesuatu yang lain. Terakhir, berkaitan dengan konsep ekspektansi. Ekspektansi adalah kekuatan dari kepercayaan seseorang mengenai apakah outcome tertentu akan tercapai atau tidak. Ada berbagai macam faktor yang memberi kontribusi bagi persepsi mengenai ekspektansi karyawan mengenai berbagai level job performance. Misalnya, tingkat kepercayaannya pada keahlian dalam melaksanakan tugas tertentu, tingkat yang membantu karyawan mengekspektasi apa yang diterima dari atasan dan bawahannya, kualitas bahan dan peralatan yang tersedia, ketersediaan informasi yang relevan dan pengendalian terhadap anggaran yang memadai (Pinder, 1984: 137).

Theory of Intentional Behavior ini dikemukakan oleh Ryan (1970). Teori ini mengasumsikan bahwa niat seseorang merupakan faktor penting dalam menjelaskan perilaku mereka. Analisis terhadap perilaku dapat dibagi menjadi 4 level atau fase yang saling berhubungan. Setiap level menjelaskan level yang mengikutinya (Pinder, 1984: 157). Niat seseorang melakukan suatu tindakan dipengaruhi oleh 3 faktor, yaitu persepsi terhadap situasi yang langsung, persepsi terhadap hubungan antara maksud dan tujuan, dan kepentingan atau ketertarikan intrinsik dari tindakan kontemplasi.

Konsep dasar yang mendasari teori ini adalah bahwa niat merupakan penyebab perilaku yang paling penting dan langsung. Untuk memahami asal dan sifat dari niat seseorang, memerlukan pemahaman mengenai cara orang memandang dunianya sendiri. Dalam rangka untuk memahami mengapa seseorang mempersepsikan sesuatu cara yang mereka lakukan, memerlukan pemahaman mengenai sifat dari produk yang disimpan seperti kebutuhan, nilai-nilai, norma-norma dan sebagainya. Akhirnya, dalam rangka untuk memahami mengapa individu memiliki kumpulan produk tersebut maka kita perlu menguji latar belakang mereka.

Goal Setting Theory ini dikembangkan oleh Locke. Latham, dan kolega mereka. Teori ini dikatakan lebih ilmiah dibandingkan dengan equity theory dan VIE theory dalam membuktikan secara empiris mengenai hubungan antara kerja (work) dengan kinerja (performance). Goals dapat berbentuk suatu level dari job performance, kuota, norma kerja, batas waktu (deadline), atau batas penggunaan anggaran (Locke, Shaw, Saari, dan Latham, 1981 yang dikutip oleh Pinder, 1984: 160). Jika goals menentukan usaha manusia, maka semakin tinggi dan semakin sulit goals dapat dicapai, maka semakin tinggi tingkat kinerja yang dihasilkan dibandingkan dengan goals yang mudah dicapai. Specific goals akan menghasilkan tingkat usaha yang lebih tinggi dibandingkan dengan goals yang tidak ditetapkan dengan jelas (vague goals). Insentif seperti uang, feedback, kompetisi, dan sejenisnya tidak akan memiliki efek pada perilaku kecuali insentif tersebut berpengaruh pada penetapan dan/atau penerimaan dari goals yang sulit dan spesifik.

Seperti telah disampaikan sebelumnya, role stress dapat terjadi ketika goals dari karyawan sebagai individu tidak sejalan dengan goals dari atasan atau manajemen (disebut role conflict) dan terjadi ketika karyawan kurang memiliki informasi mengenai tugas yang harus mereka lakukan (disebut role ambiguity). Penelitian-penelitian mengenai role stress telah menunjukkan konsekuensi munculnya role stress ini, yaitu penurunan job satisfaction dan job performance serta peningkatan job-related tension dan turnover intentions. Porter dan Lawler (1968) serta Lawler (1971) mengembangkan model job satisfaction seperti terlihat dalam Gambar 1 (Ferris, 1977a). 


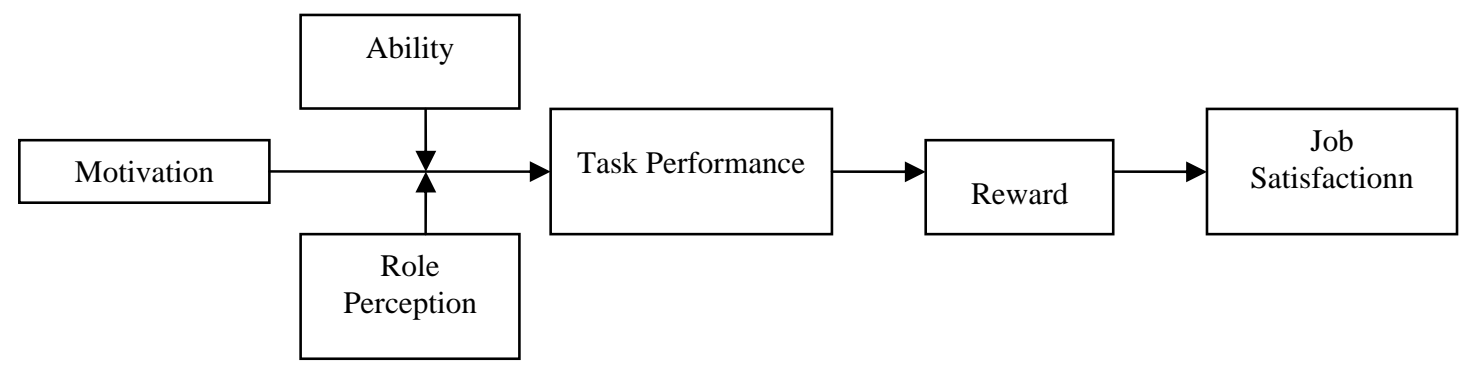

Gambar 1 Model Job Satisfaction

Pada Gambar 1, terlihat bahwa kinerja merupakan joint function dari tingkat motivasi individual, kemampuan (ability) dalam kaitannya dengan pekerjaan dan luas di mana persepsi perannya sesuai dengan atasannya. Kemampuan dalam kaitannya dengan pekerjaan berhubungan positif dengan persepsi terhadap peran (Ferris, 1977b). Motivasi dapat meningkatkan kinerja ketika persepsi peran bawahan sesuai dengan atasan (di samping bawahan juga memiliki kemampuan tertentu untuk melaksanakan tugas). Role stress (role conflict maupun role ambiguity) muncul karena adanya persepsi peran yang berbeda antara atasan dan bawahan atau antara ketua kelompok dan anggota kelompok, maka motivasi akan menurunkan kinerja, yang pada akhirnya akan menimbulkan job dissatisfaction.

\section{PEMBAHASAN}

Sesuai dengan motivator-hygiene theory, role stress dapat kita masukkan sebagai hygiene factor yang dapat mengakibatkan job dissatisfaction. Menurut teori ini, role stress dapat meningkatkan kinerja ketika atasan atau ketua kelompok menggeser mekanisme dan mengubahnya menjadi motivasi. Jadi, role stress dapat menjadi motivator ketika manajemen dapat menggeser mekanisme dan mengubahnya menjadi motivasi. Penggeseran mekanisme dilakukan karena mekanisme yang diterapkan sebelumnya tidak sesuai dengan karakteristik bawahan atau anggota kelompok. Jadi dalam hal ini, perlu adanya modifikasi terhadap desain pekerjaan. Hackman dan Oldham (1976) mengatakan bahwa untuk mendesain pekerjaan yang secara internal dapat memotivasi karyawan dalam melaksanakan pekerjaannya secara efektif diperlukan 3 hal, yaitu pernyataan psikologis dari karyawan yang harus ada untuk memotivasi kerja mereka, karakteristik pekerjaan yang dapat menghasilkan pernyataan psikologis ini, dan atribut-atribut individual yang menentukan bagaimana orang akan merespon secara positif pekerjaan yang menantang dan kompleks.

Apabila kita kaitkan dengan theory $X$ dan theory $Y$, maka role stress dapat terjadi ketika atasan (ketua kelompok) mengasumsikan bahwa bawahan (anggota kelompok) memiliki karakteristik personal seperti yang dikemukakan dalam theory $X$; padahal mereka sebenarnya memiliki karakteristik personal seperti yang dikemukakan dalam theory $Y$ dan juga sebaliknya. Oleh karena itu, atasan (ketua kelompok) perlu memahami terlebih dahulu bagaimana karakteristik personal dari bawahannya (anggota kelompok) sebelum memberikan tugas pada mereka sehingga role stress tidak akan terjadi pada mereka. Apabila role stress sudah terjadi karena ketidaksesuaian tugas yang diberikan dengan karakteristik personal bawahan (anggota kelompok), maka atasan perlu dilakukan modifikasi terhadap tugas yang diberikan sehingga sesuai dengan karakteristik bawahannya.

\section{Proposisi 1}

Role stress akan meningkatkan kinerja auditor ketika terdapat kesesuaian antara tugas dengan karakteristik personal dari auditor tersebut. Role stress juga dapat dijelaskan dengan equity theory. 
Teori ini menyatakan bahwa ketika seseorang diperlakukan tidak adil oleh bawahan karena ia mempersepsikan kontribusi yang telah ia berikan dihargai lebih rendah dibandingkan kontribusi yang diberikan orang lain maka mereka akan mengalami kecemasan dan stres yang akhirnya menurunkan kinerjanya. Hal ini dapat terjadi karena adanya asimetri informasi antara atasan (ketua kelompok) dengan bawahan (anggota kelompok). Seperti telah dikemukakan sebelumnya bahwa adanya boundary spanning activities yang membatasi kemampuan individu untuk mencari informasi yang sebanyakbanyaknya dan karena adanya ketidakpastian lingkungan yang dipersepsikan mengakibatkan role stress terjadi. Dalam keadaan seperti ini, peran atasan (ketua kelompok) dalam mengubah role stress menjadi motivator adalah dengan menggeser mekanisme pemberian tugasnya, yaitu dengan cara mengurangi ketidakpastian lingkungan dan mempermudah bawahan (anggota kelompok) mencari informasi sebanyak-banyaknya.

\section{Proposisi 2}

Role stress akan meningkatkan kinerja auditor ketika ketidakpastian lingkungan persepsian rendah. VIE theory atau expectancy theory berkaitan dengan keseimbangan antara keinginan untuk mencapai outcome tertentu (valensi), kemampuan outcome yang akan dicapai mempengaruhi pencapaian outcome yang lain (instrumental) dan kemampuan untuk mencapai outcome tersebut (ekspektansi). Role stress dapat terjadi karena adanya valensi negatif dari seseorang yang akhirnya akan mengakibatkan penurunan kinerja dan job dissatisfaction. Untuk mengubah role stress menjadi motivator, atasan (ketua kelompok) perlu mengubah outcome yang harus dicapai sehingga valensi akan berubah menjadi positif.

\section{Proposisi 3}

Role stress akan meningkatkan kinerja auditor ketika mekanisme pemberian reward dan punishment sesuai dengan karakteristik personal dari auditor tersebut. Menurut theory of intentional behavior, role stress terjadi karena niat seseorang dalam melaksanakan tugas tidak sesuai dengan keinginan atasan (ketua kelompoknya). Hal ini disebabkan atasan (ketua kelompok) tidak memahami kebutuhan, nilai-nilai, dan norma-norma yang ada di dalam diri bawahan (anggota kelompok). Penelitian menunjukkan bahwa role stress disebabkan oleh adanya Organizational-Professional Conflict (OPC). Oleh karena itu, cara untuk mengubah role stress menjadi motivator adalah dengan mengubah mekanisme pemberian tugas dengan mempertimbangkan kebutuhan, nilai-nilai, dan normanorma yang dimiliki oleh bawahan (anggota kelompoknya).

\section{Proposisi 4}

Role stress akan meningkatkan kinerja auditor ketika terdapat pemahaman terhadap kebutuhan, nilai-nilai, dan norma-norma organisasi. Terakhir, atas dasar goals setting theory, role stress dapat terjadi karena adanya perbedaan antara persepsi terhadap goals yang harus dicapai dengan yang seharusnya dicapai oleh bawahan (anggota kelompok). Hal ini disebabkan oleh adanya vague goals dan difficult goals yang ditetapkan oleh organisasi. Oleh karena itu, untuk mengurangi atau menghilangkan role stress, diperlukan specific goals dan kemudahan untuk mencapai goals. Dalam hal ini, peran partisipasi bawahan dalam penetapan goals dan feedback dari atasan akan sangat berguna untuk menurunkan tingkat role stress.

\section{Proposisi 5}

Role stress akan meningkatkan kinerja auditor ketika terdapat goal commitment dari seluruh individu dalam organisasi. 


\section{PENUTUP}

Role stress merupakan fenomena organisasional yang terjadi dalam hubungan dinamis antar individu-individu di dalam organisasi. Oleh karena itu, fenomena ini tidak harus dipandang sebagai sesuatu yang negatif karena hubungan antar individu di dalam organisasi bersifat jangka panjang dan bukan merupakan hubungan yang sesaat sehingga di dalam dinamika organisasi, role stress ini justru akan menjadi motivator bagi karyawan untuk meningkatkan kinerjanya. Kemunculan role stress di dalam suatu organisasi diharapkan dapat memberi sinyal bagi manajemen bahwa telah terjadi ketidaksesuaian mekanisme yang dijalankan organisasi. Dengan demikian, manajemen dapat melakukan tindakan untuk mengatasinya.

Partner dan auditor senior di dalam KAP dapat mengubah role stress dari hygiene factor menjadi motivator bila ia memahami dengan baik karakteristik organisasi beserta anggota-anggotanya. Dengan menggunakan teori motivasi, masalah role stress di dalam KAP dapat diatasi. Dengan motivator-hygiene theory, role stress dapat berubah menjadi motivator bila manajemen dapat menggeser mekanisme pelaksanaan tugas yang selama ini dijalankan. Dengan memahami theory $X$ dan $Y$, partner dan auditor senior juga dapat mengurangi atau menghilang role stress dengan memahami dengan baik karakteristik individu di dalam organisasi serta iklim organisasi sehingga desain tugas yang dibuat akan memotivasi karyawan untuk melaksanakan pekerjaannya. Jadi, auditor akan termotivasi untuk meningkatkan kinerjanya ketika mengalami role stress jika atasan (partner atau auditor senior) dapat menyesuaikan tugas dengan karakteristik personal dari bawahannya.

Atas dasar equity theory, maka partner dan auditor senior dapat mengatasi role stress dengan mengurangi boundary-spanning activities dan ketidakpastian lingkungan persepsian. Atas dasar VIE theory, untuk mengubah role stress menjadi motivator, maka partner atau auditor senior perlu mengubah outcome yang harus dicapai sehingga valensi akan berubah menjadi positif. Hal ini dapat dilakukan dengan menyesuaikan mekanisme reward dan punishment dengan karakteristik personal dari individu-individu di dalam organisasi. Menurut theory of intentional behavior, role stress dapat dikurangi atau dihilangkan bila terdapat pemahaman mengenai kebutuhan, nilai-nilai, dan normanorma yang di dalam organisasi. Terakhir, atas dasar goals setting theory, role stress dapat dikurangi atau dihilangkan dengan cara membuat specific goals dan goals yang mudah dicapai. Selain itu, peran partisipatif karyawan dalam penetapan goals dan feedback dari atasan akan mendukung usaha penurunan role stress. Oleh karena itu, goal commitment dianggap menjadi faktor yang dapat mengubah role stress menjadi motivator bagi pencapaian kinerja. Semua uraian di atas dapat membantu kita untuk membuat model hubungan role stress dengan motivasi kerja dan kinerja sebagai terlihat dalam Gambar 2.

Analisis teoritis ini diharapkan dapat memberi masukan bagi manajemen (partner dan auditor senior) di dalam KAP dalam meningkatkan kinerja karyawan, yaitu dengan cara mendesain tugastugas bagi auditor yunior, mendesain mekanisme pemberian reward dan punishment yang sesuai dengan karakteristik individu-individu di dalam organisasi, menyediakan sistem yang memungkinkan auditor mencari informasi sebanyak-banyaknya, baik informasi internal maupun eksternal yang berkaitan dengan kliennya, sosialisasi terhadap nilai-nilai dan norma-norma organisasi, dan memberikan kejelasan mengenai goals yang harus dicapai sehingga individu-individu akan memiliki komitmen terhadap goals tersebut. Selain itu, juga diharapkan dapat memberi inspirasi untuk melakukan studi empiris, dalam kaitannya dengan role stess yang dapat digunakan sebagai motivator bagi individu dalam meningkatkan kinerja. 


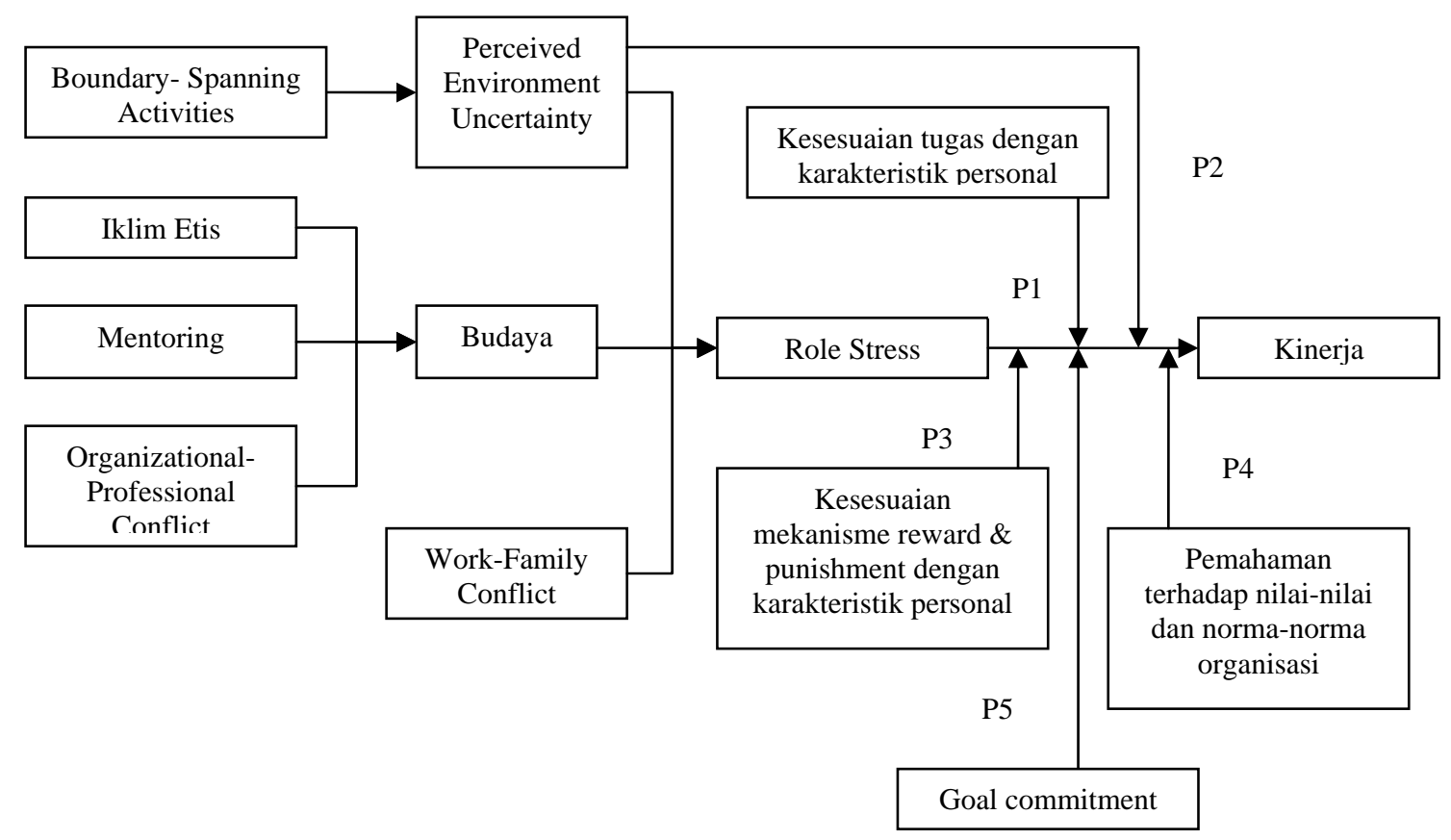

Gambar 2 Model Hubungan Role Stess, Motivasi Kerja dan Kinerja

\section{DAFTAR PUSTAKA}

Almer, E.D., and Kaplan, S.E. (2002). The effects of flexible work arrangements on stressors, burnout, and behavioral job outcomes in public accounting. Behavioral Research in Accounting, 14, 134 .

Aranya, N., and Ferris, K.R. (1984). A reexamination of accountants' organizational-professional conflict. The Accounting Review, 59(1), 1-15.

Aranya, N., Pollock, J., and Amernic, J. (1981). An examination of professional commitment in public accounting. Accounting, Organizations and Society, 6(4), 271-280.

Bamber, E.M., and Iyer, V.M. (2002). Big 5 auditors' professional and organizational identification: Consistency or conflict?. Auditing, 21(2), 21-38.

Belkauoi, A. (1989). Behavioral accounting: The research and practical issues, New York: Greenwood Press, Inc.

Chia-Mei, S., and Chin-Yuan, C. (2006). The effect of organizational ethical culture on marketing managers' role stress and ethical behavioral intentions. Journal of American Academy of Business, Cambridge, 8(1), 89-95.

Chonko, L.B., and Burnett, J.J. (1983). Measuring the importance of ethical situations as a source of role conflict: A survey of salespeople, sales managers, and sales support personnel. Journal of Personal Selling \& Sales Management, 3(1), 41. 
Chow, C.W., Lindquist, T.M., and Wu, A. (2001). National culture and the implementation of highstretch performance standards: An exploratory study. Behavioral Research in Accounting, 13, 85-109.

Collins, K.M., and Larry N.K. (1992). An empirical examination of stress in public accounting. Accounting, Organizations and Society, 17 (6), 535-47.

Elloy, D.F.W.T, and Kohls, J. (2001). A causal model of burnout among self-managed work team members. Journal of Psychology, 135(3), 321.

Farrell, M. (2005). The effect of a market-oriented organisational culture on sales force behaviour and attitudes. Journal of Strategic Marketing, 13(4), 261-273.

Ferris, K.R. (1977a). Perceived uncertainty and job satisfaction in the accounting environment. Accounting, Organizations and Society, 2(1), 23-28.

Ferris, K.R. (1977b). A test of the expectancy theory of motivation in an accounting environment. The Accounting Review, 52(3), 605-615.

Fisher, R.T. (2001). Role stress, the type a behavior pattern, and external auditor job satisfaction and performance. Behavioral Research in Accounting, 13, 143.

Gilboa, S., Shirom, A., and Fried, Y. (2005). A meta-analysis of stress and performance at work: Moderating effects of gender, age, and tenure. Academy of Management Proceedings, A1-A6.

Hackman, R.J., and Greg R.O. (1976). Motivation through the design of work: Test of a theory. Organizational Behavior and Human Performance, 16, 250-279.

Harrison, P.D., Chow, C.W., Wu, A., and Harrell, A.M. (1999). A cross-cultural investigation of managers' project evaluation decisions. Behavioral Research in Accounting, 11, 143-160.

Jaramillo, F., Mulki, J.P., and Solomon, P. (2006). The role of ethical climate on salesperson's role stress, job attitudes, turnover intention, and job performance. Journal of Personal Selling \& Sales Management, 26(3), 271-282.

Maher, M.W., Ramanathan, K.V., and Peterson, R.B. (1979). Preference congruence, information accuracy, and employee performanca: A field study. Journal of Accounting Research, 17(2 Autumn), 476-503.

Miler, J.B. (1980). Theories of organizational behavior, Illinois: The Dryden Press.

Nygaard, A., and Dahlstrom, R. (2002). Role stress and effectiveness in horizontal alliances. Journal of Marketing, 66(2), 61-82.

Pei, B.K.W., and Davis, F.G. (1989). The impact of organizational structure on internal auditor organizational-professional conflict and role stress: An exploration of linkages. Auditing, 8(2), 101.

Pinder, C.C. (1984). Work motivation: Theory, issues, and applications, London: Scott, Foresman and Company.

Rebele, J.E., and Michaels, R.E. (1990). Independent auditors' role stress: Antecedent, outcome, and moderating variabel. Behavioral Research in Accounting, 2, 124. 
Sinatra, P.T. (1980). Role conflict, role ambiguity, and organizational climate in a public accounting firm. The Accounting Review, LV(4), 594-603.

Veloutsou, C.A., and Panigyrakis, G.G. (2004). Consumer brand managers' job stress, job satisfaction, perceived performance, and intention to leave. Journal of Marketing Management, 20(1/2), 105-131.

Viator, R.E. (2001). The association of formal and informal public accounting mentoring with role stress and related job outcomes. Accounting, Organizations and Society, 26, 73-93. 